\title{
Dietrich Bonhoeffer: 'n Lewe in die voetspore van Christus
}

\begin{tabular}{|c|c|}
\hline $\begin{array}{l}\text { Author: } \\
\text { Robert Jones }^{1}\end{array}$ & \\
\hline $\begin{array}{l}\text { Affiliation: } \\
{ }^{1} \text { Department } \\
\text { Testament Stu } \\
\text { of Theology, } \\
\text { Pretoria, Sout }\end{array}$ & $\begin{array}{l}\text { f New } \\
\text { dies, Faculty } \\
\text { niversity of } \\
\text { Africa }\end{array}$ \\
\hline $\begin{array}{l}\text { Note: } \\
\text { Dr Robert Jone } \\
\text { as research as } \\
\text { of Prof. Dr Ern } \\
\text { Eck, Departme } \\
\text { Testament Stu } \\
\text { of Theology, U } \\
\text { Pretoria, Soutl }\end{array}$ & $\begin{array}{l}\text { es participates } \\
\text { sociate } \\
\text { est van } \\
\text { nt of New } \\
\text { dies, Faculty } \\
\text { niversity of } \\
\text { Africa. }\end{array}$ \\
\hline $\begin{array}{l}\text { Corresponden } \\
\text { Robert Jones }\end{array}$ & ce to: \\
\hline $\begin{array}{l}\text { Email: } \\
\text { rjjones@nhk.c }\end{array}$ & \\
\hline $\begin{array}{l}\text { Postal address } \\
\text { Private Bag X2 } \\
\text { 0028, Pretoria }\end{array}$ & $\begin{array}{l}\text { 0, Hatfield } \\
\text {, South Africa }\end{array}$ \\
\hline $\begin{array}{l}\text { Dates: } \\
\text { Received: } 17 \mathrm{~J} \\
\text { Accepted: } 31 \mathrm{~J} \\
\text { Published: } 23\end{array}$ & $\begin{array}{l}\text { une } 2015 \\
\text { uly } 2015 \\
\text { Oct. } 2015\end{array}$ \\
\hline $\begin{array}{l}\text { How to cite th } \\
\text { Jones, R., } 2015 \\
\text { Bonhoeffer: 'n } \\
\text { voetspore van } \\
\text { HTS Teologiese } \\
\text { Theological St } \\
\text { Art. \#3087, } 7 \\
\text { dx.doi.org/10. } \\
\text { v71i3.3087 }\end{array}$ & $\begin{array}{l}\text { is article: } \\
\text {, 'Dietrich } \\
\text { Lewe in die } \\
\text { Christus', } \\
\text { Studies/ } \\
\text { udies 71(3), } \\
\text { ages. http:// } \\
\text { 4102/hts. }\end{array}$ \\
\hline $\begin{array}{l}\text { Copyright: } \\
\text { (C) 2015. The A } \\
\text { Licensee: AOSI } \\
\text { OpenJournals. } \\
\text { licensed under } \\
\text { Commons Attr } \\
\text { License. }\end{array}$ & $\begin{array}{l}\text { uthors. } \\
\text { This work is } \\
\text { the Creative } \\
\text { ibution }\end{array}$ \\
\hline 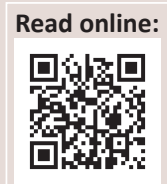 & $\begin{array}{l}\text { Scan this QR } \\
\text { code with your } \\
\text { smart phone or } \\
\text { mobile device } \\
\text { to read online. }\end{array}$ \\
\hline
\end{tabular}

Dietrich Bonhoeffer: A life in the footsteps of Christ. The life of Dietrich Bonhoeffer was a life devoted to the following of Jesus Christ. This article aims to contextualise Bonhoeffer's thoughts concerning discipleship against the background of Nazi Germany where he chose to stay in the years leading up to and during World War II. It is argued that the circumstances under which he lived and worked gave impetus to his understanding of discipleship, preventing this understanding of discipleship from being only abstract thoughts. A few remarks will be made about Bonhoeffer's thoughts on discipleship, which will then be read against the background of Jesus' call to discipleship in Mark 8:34.

\section{Inleidend}

Wanneer die teologie van Dietrich Bonhoeffer gelees word, kan dit nie losgemaak word van die omstandighede wat hy in Duitsland beleef het nie. Die Duitsland waarin Bonhoeffer geleef en gewerk het, het na my mening 'n vormende rol in sy teologie en verstaan van die evangelie gespeel. Dit gee aan sy verstaan van die navolging van Christus substansie omdat hy uitgedaag is om hierdie navolging konkreet uit te leef in omstandighede wat nie met die liefde van die evangelie gestrook het nie. Daarom sal dit die moeite loon om eers iets raak te sien van die omstandighede in Duitsland in Bonhoeffer se tyd alvorens ' $n$ mens oor sy navolging van Christus en die betekenis daarvan vir Christene vandag praat.

Hierdie artikel het ten doel om aan te toon dat die omstandighede in Duitsland tussen 1906 en 1945 daartoe bygedra het dat Bonhoeffer se denke oor die navolging van Christus op 'n konkrete wyse verstaan kan word. Verder word ook aangetoon dat hy sy gedagtes oor die navolging van Christus prakties uitgeleef het totdat hy op 09 April 1944 in die Flossenburg-konsentrasiekamp op 39-jarige ouderdom met sy lewe daarvoor betaal het.

\section{Historiese agtergrond Duitsland in die tyd van Bonhoeffer (1906-1945)}

Bonhoeffer beleef die laaste twee van drie eras in die tydperk 1871-1945 in Duitsland, elk met 'n regering wat sy eie klem dra. ${ }^{1}$ Die laaste era (1933-1945) was wreed en die slegste van die drie as gevolg van Hitler se optrede. In hierdie tydperk, tydens die bewind van Adolf Hitler, preek Bonhoeffer en publiseer hy van sy werke.

In 1930 wen die Nasionaal Sosialistiese party van Adolf Hitler 112 setels in die parlement in vergelyking met die 12 wat hulle tot op daardie stadium gehad het. Hierdie groei het dit vir hulle moontlik gemaak om met ander ekstreme regse partye hande te vat.

In 1933 word Hitler kanselier van Duitsland. Hy belowe Duitsland 'n blink toekoms wat hy sou waarmaak deur toe te sien dat Duitsland se ekonomie en al die ander dinge reggestel word wat na die Eerste Wêreldoorlog as gevolg van die voorwaardes vir Duitsland se oorgawe skade gely het, soos vervat in die verdrag van Versailles. ${ }^{2}$ Hy maak sy eie politieke planne om dit te doen en duld geen teenstand van enige instansie, ander politieke partye en selfs sy eie Naziparty nie.

Twee sake wat baie prominent was in Hitler se 'hervorming' van Duitsland was die herstel van die Duitse ekonomie en die implementering van 'n anti-Joodse of anti-Semitiese beleid. Volgens Moses (2002:4) het dit drie ander belangrike sake tot gevolg gehad, naamlik die voorbereiding vir oorlog, die weiering om internasionale skuld te betaal en die vervolging van enige iemand van

1.Die Keiserryk (1871-1918), die Weimar-republiek (1919-1933) en die Derde Ryk (1933-1945)

2.Keiser Wilhelm het reeds in 1894 'n soortgelyke belofte aan die Duitse volk gemaak. 
Joodse afkoms. Moses (2002) som die realiteit van die situasie in Duitsland aan die begin van die Tweede Wêreldoorlog soos volg op:

One of the great tragedies of German history is that the opposition to these disastrous policies from Germans themselves was notoriously weak. The army, the church and the representatives of the former political parties, with few notable exceptions, were either unable to mount a sustained critique of the Nazi regime or, least of all, engage in conspiratorial action against it. Dietrich Bonhoeffer must be counted among the most outstanding of these exceptions. (bl. 5)

Nadat Hitler se kabinet in 1933 aan bewind gekom het en baie setels gehad het, was dit vir die Duitse volk die teken dat Duitsland besig is om op te staan uit die vernedering na die Eerste Wêreldoorlog. Hulle het geoordeel dat die vroeëre Duitse kultuur wat hulle van die Ooste (kommunisme) en die Weste (liberalisme) onderskei het, nou onder Hitler se leierskap voortgesit kon word. Moses (2002) verduidelik die politieke verandering in Duitsland nadat Hitler aan bewind gekom het soos volg:

This [die politieke verandering in Duitsland], of course, was the delusion Hitler and his staff were pleased to sustain. But Hitler was not a reincarnation of Bismarck; he was a totally new phenomenon which had challenged historians, political scientists, sociologists and psychologists to advance a satisfactory explanation. (bl. 17)

Die afleiding kan dus gemaak word dat die NasionaalSosialisme aan die vryheid van die genoemde studievelde perke begin stel het om hulle ideologie te bevorder. Hieronder het die kerk ook gely. Hitler het die kerk begin infiltreer en die kerk staatskerk gemaak.

So is ook geestelike leiers geïndoktrineer en beperkings aan hulle gestel. Hier kan spesifiek verwys word na die opdrag aan Bonhoeffer dat hy geen stukke meer mag publiseer, of in die openbaar mag praat of preek nie. Bonhoeffer skryf na sy eerste besoek aan Switserland in 'n brief gedateer 30 Mei 1941 aan Karl Barth:

Like others, I too have been prohibited from publishing. There is a good chance I can come to your country again for a few weeks in late summer in order to work and write. ${ }^{3}$ (Godsey 1982:2)

So het die Nazi's gepoog om ook die Christelike geloof te swaai na 'n ideologie wat aanklank vind by en gedra word deur die ideologie van Nasionaal-Sosialisme.

Hitler se beleid en program sou nie kon realiseer indien hy hom nie met mense wat een honderd persent lojaal teenoor hom was, omring het en hulle in sleutelposisies aangestel het nie. ${ }^{4}$ Verder sou niks ook kon werk of sou hy nie sy doel kon bereik indien hy nie die ondersteuning en lojaliteit van die

3.In Junie 1981 ontdek die vrou van dr. Hinrich Stoevensandt, kurator van die Karl Barth-argief in Basel, Switserland, ses briewe van Dietrich Bonhoeffer aan Barth Barth-argief in Basel, Switserland, ses briewe van Dietrich Bonhoeffer aan Barth, terwyl sy deur literatuur van Charlotte von Kirsbaum gesoek het. Die briewe dateer 1942. Hierdie briewe was gerig aan Karl Barth en aan van die mense na aan hom.

4. Hier kan verwys word na persone soos Albert Speer en Heinrich Himler, die hoof van die SS (Schutz-Staffel), wat absoluut lojaal was teenoor Hitler. weermag gehad het nie. Tog was daar wel 'n deel van die Duitse weermag wat teen Hitler gekant was en geoordeel het dat hy nie bevoeg was om leier van Duitsland te wees nie. Dietrich Bonhoeffer se sentiment het by hierdie groep gelê. Dit bevestig Moses (2002) met die volgende stelling:

Only a handful of officers had sufficient reservations to consider deposing Hitler on the grounds that he was incompetent as a military planner and would lead Germany to destruction. This was the rationale for the conspiracy of officers against Hitler that led to the ill-fated assassination attempt of 20 July 1944, with which Dietrich Bonhoeffer was associated. (bl. 18)

Die situasie in Duitsland in die tyd van Bonhoeffer word deur Metaxas (2010:149) baie goed in die volgende woorde saamgevat: 'With the tools of democracy, democracy was murdered and lawlessness made "legal". Raw power ruled, and its only real goal was to destroy all other powers besides itself.'

\section{Kerkstryd}

In 'n ontmoeting tussen Hitler en Martin Niemöller, predikant in Dahlem, Berlyn, in 1932 gee Hitler aan Niemöller die versekering dat hy geen invloed sal uitoefen op die kerk nie en ook geen veldtog teen die Jode sal instel nie. Kort daarna gaan Hitler terug op sy woord en gebeur die teenoorgestelde. Niemöller draai teen Hitler. Daarna ontmoet Niemöller vir Bonhoeffer en begin Niemöller 'n beduidende rol speel in die kerkstryd. Hitler verwoord sy siening van Protestantse predikante soos volg: 'You can do anything you want with them ...They will submit ...they are insignificant little people, submissive as dogs, and they sweat with embarrassment when you talk to them' (Metaxas 2010:180).

In 1933 stel Hitler vir Ludwig Müller aan as Reichsbischoff om toe te sien dat daar eenheid bewerk word tussen al die verskillende dele van die kerk in Duitsland. Müller verduidelik sy siening van hoe die kerk behoort te lyk soos volg:

... the 'love' of the German Christians had a 'hard, warrior-like face. It hates everything soft and weak because it knows that all life can only then remain healthy and fit for life when everything antagonistic to life, the rotten and the indecent, is cleared out of the way and destroyed'. (Metaxas 2010:178-179)

Müller beveel op 28 Junie 1933 dat Duitse troepe die kerkkantoor in Berlyn beset. So begin die kerkstryd. Müller sou so ver gaan as om geweld te gebruik om beheer oor die kerk uit te oefen. Bonhoeffer sien egter een moontlikheid vir hoe die kerk hierop kan reageer om sy punt te maak. Metaxas (2010) verwoord dit soos volg:

But Bonhoeffer and Hildebrandt saw one possibility. They suggested that the churches effectively go on strike against the state to assert their independence. If the state did not pull back and let the church be church, the church would cease behaving like the state church and would, among other things, stop performing funerals. It was a brilliant solution. (bl. 179)

Die opmerking moet egter gemaak word dat die meeste Christene in Duitsland Christenskap en die Nasionaal- 
Sosialisme beskou het as twee sake wat nie met mekaar versoenbaar is nie. Ook Karl Barth het hieroor die opmerking gemaak dat daar 'n kloof tussen Christenskap en die godloosheid van die Nasionaal-Sosialisme bestaan (kyk na Metaxas 2010:171).

Dit is al hierdie sake wat vir Bonhoeffer dwars in die krop gesteek het en nie gestrook het met wat die evangelie van Jesus Christus geleer en gevra het nie.

\section{Bonhoeffer se plek is by sy mense}

By verskeie geleenthede het Bonhoeffer dit duidelik gemaak dat hy tydens die oorlog by sy mense in Duitsland moet wees. Bonhoeffer was oortuig dat hy nie na die oorlog sy mense sou kon begelei as hy nie tydens die oorlog saam met hulle gely het en by hulle was nie. Daarom wou hy nie in die buiteland wees terwyl sy mense in Duitsland swaarkry en leiding nodig het nie. Hierdie standpunt word duidelik uit briefwisseling tussen hom en Karl Barth. Tydens 'n besoek aan Londen in 1934 skryf Bonhoeffer aan Barth dat hy as gevolg van sy siening oor die destydse situasie van die kerk in Duitsland geïsoleerd voel en besig is om van sy kollegas vervreemd te raak. Hierop antwoord Barth soos volg:

And now, as you are mentioning the matter to me before the fact, I can honestly not tell you anything but 'Hurry back to your post in Berlin!'... Be glad that I do not have you here in person, for I would let go at you urgently in quite a different way, with the demand that you must not let go of all these intellectual flourishes and special considerations, however interesting they may be, and think of only one thing - that you are a German, that the house of your church is on fire, that you know enough and can say what you know well enough to be able to help, and that you must return to your post by the next ship. (Metaxas 2010:197-198)

Op 23 Januarie 1939 kry Bonhoeffer die nuus dat alle mans wat in 1906 en 1907 gebore is vir militêre diens moet registreer. Indien hy sou weier om vir militêre diens aan te meld omdat hy nie die Führer-beginsel ${ }^{5}$ en die NasionaalSosialisme ondersteun nie, het die moontlikheid bestaan dat hy gearresteer en selfs tereggestel kon word. Indien 'n predikant van die Belydende Kerk sou weier om militêre diens te doen, kon dit skadelik wees vir almal wat deel was van die Belydende Kerk. Die persepsie kon by die ander predikante van die Belydende Kerk ontstaan dat Bonhoeffer dieselfde van hulle verwag, wat nie die geval was nie. Daar was wel vir Bonhoeffer die moontlikheid om aan militêre diens te ontkom deur Amerika toe te gaan en daar vir die ekumeniese beweging te werk. Dit sou sy militêre diens met een jaar kon uitstel. Hy skryf soos volg hieroor aan 'n vriend in Engeland, Biskop George Bell: 'I'm thinking of leaving

5.Metaxas (2010:141) verwys na Bonhoeffer se siening oor die Führer-beginsel: 'The good leader serves others and leads others to maturity. He puts them above himself, as a good parent does a child, wishing to lead that child to someday be himself, as a good parent does a child, wishing to lead that child to someday be a good parent. Another word for this is discipleship.' Op 01 Februarie 1933 lewe Bonhoeffer ' $n$ toespraak oor die Potsdamerstrasse-radiostasie oor die Führerbeginsel. In hierdie toespraak het hy dit nie teen Hitler nie, maar teen die beginse van 'n Führer wat Duitsland regeer. Volgens Bonhoeffer kon 'n Führer maklik verhe word tot ' $\mathrm{n}$ ikoon en die volk mislei. So ' $\mathrm{n}$ ikoon word gesien as ' $\mathrm{n}$ soort messias. Dit gaan vir so 'n leier oor selfverryking en om mag in te palm. Metaxas (2010:364) vat Bonhoeffer se denke oor die Führer-beginsel soos volg saam: 'He [Bonhoeffer] knew that if Germany worshiped any idol, it would incinerate its own future ...'
Germany sometime. The main reason is the compulsory military service to which the men of my age (1906) will be called up this year' (Metaxas 2010:322).

Op hierdie stadium het die Belydende Kerk nog nie 'n standpunt oor die dreigende oorlog ingeneem nie. Bonhoeffer kon nie weet wat die gevolge daarvan vir sy kollegas sou wees indien hy sou weier om vir militêre diens aan te meld nie. Hy stel dit soos volg in dieselfde brief aan George Bell:

So I should cause a tremendous damage to my brethren if I would make a stand on this point which would be regarded by the regime as typical of the hostility of our church toward the state. Perhaps the worst thing of all is the military oath I should have to swear. So I am rather puzzled in this situation, and perhaps even more because I feel it is really only on Christian grounds that I find it difficult to do military service under the present conditions, and yet there are only few friends who would approve of my attitude. (Metaxas 2010:322)

Op 03 April 1339 ontmoet Bonhoeffer die Amerikaanse teoloog Niebuhr in Sussex en verduidelik sy dilemma aan Niebuhr. Indien Bonhoeffer 'n amptelike uitnodiging ontvang om in Amerika te werk, kan dit sy probleem gedeeltelik oplos. Metaxas (2010:323) som Niebuhr se reaksie op Bonhoeffer se versoek soos volg op: 'Niebuhr realized the urgency of the situation and leaped into action. He would pull what strings he could.' Metaxas (2010) beskryf die situasie verder soos volg:

Within days, Niebuhr's letters generated a hive of activity across the Atlantic: phone calls were made, meetings were called, plans were changed, and more letters were written, all in the frantic but excited hopes of rescuing Bonhoeffer from imminent danger, not to mention bringing the brilliant young theologian into their spheres of orbit. There was a giddy tone to the whole affair, and Bonhoeffer had no idea of the extraordinary efforts being made on his behalf. (bl. 325)

Op 04 Junie 1939 vertrek Bonhoeffer na Amerika. Hy was steeds nie seker of hy die regte ding doen nie en het steeds gewonder of hy nie eerder moet teruggaan Duitsland toe nie. Hy skryf op 15 Junie 1939 die volgende in sy dagboek:

Since yesterday evening I haven't been able to stop thinking about Germany. I would not have thought it possible that at my age, after so many years abroad, one could get so dreadfully homesick ... I would gladly have taken the next ship home ... I was in utter despair. (Metaxas 2010:330)

Sy verblyf in Amerika en die kwessie of hy moet teruggaan Duitsland toe, was steeds vir Bonhoeffer 'n worsteling. 'n Teks uit Jesaja, 'Wie op My vertrou, hoef nie te vlug nie' (Jes 28:16), het hom op die ou end oortuig om die besluit te neem om terug te gaan Duitsland toe. Op 07 Julie 1939 vertrek Bonhoeffer uit Amerika op pad terug na Duitsland.

\section{Jesus se oproep tot dissipelskap Dissipelskap volgens die evangelie van Markus}

Omdat die doel van hierdie artikel is om Bonhoeffer se gedagtes oor dissipelskap teen die agtergrond van Jesus se 
oproep tot dissipelskap in Markus 8:34 te lees, sal dit die moeite loon om te kyk na hoe Markus die navolging van Jesus in sy verhaal oor Jesus verstaan en verwoord. Eerstens sal die punt gemaak word dat dissipelskap vir Markus met die lyding van Jesus verband hou. Tweedens sal kommentaar gelewer word op die drie dele van Jesus se oproep tot dissipelskap in Markus 8:34 naamlik selfverloëning, die kruis opneem en navolging.

Markus plaas in drie gedeeltes die fokus op dissipelskap, te wete Markus 8:34-38; 9:35-37 en 10:42-45. Elk van hierdie drie volg nadat Jesus sy lyding aangekondig het. In al drie hierdie gedeeltes is Jesus aan die woord en antwoord Hy sy dissipels nadat dit duidelik word dat hulle nie verstaan dat lyding deel is van dissipelskap nie. Binne die groter struktuur van die Markus-evangelie maak hierdie drie gedeeltes deel uit van die middelste deel van Markus, naamlik waar Jesus en sy dissipels vanaf Galilea op pad is na Jerusalem. ${ }^{6}$

Op pad na Jerusalem verstaan die dissipels nie wat Jesus se lyding beteken nie. Die onkunde van die dissipels word verwoord in die drie Markus-tekste hierbo genoem. Petrus neem vir Jesus eenkant toe en berispe Hom nadat Hy die eerste keer sy lyding aankondig (Mark 8:32-33). Die dissipels stry oor wie die belangrikste gaan wees in die koninkryk van God (Mark 9:36-37). Johannes en Jakobus wil aan Jesus se linker- en regterkant sit wanneer Hy as Koning heers (Mark 10:35-37). Die dissipels weet dus nie wat dit werklik is wat Jesus van hulle vra nie.

Jesus antwoord op sy dissipels se onkunde deur te verduidelik dat dit in die koninkryk van God anders werk as in die wêreld. Dít verstaan die dissipels nie. Wanneer die dissipels onder mekaar stry oor wie die belangrikste in die koninkryk van God is (Mark 9:34), antwoord Jesus hulle deur 'n kind nader te roep (Mark 9:36-37) en maak dit dan vir hulle duidelik dat dié wat in die oë van die wêreld klein is en niks beteken nie, groot is in die koninkryk van God. Wanneer Johannes en Jakobus vra om een aan Jesus se linker- en een aan sy regterkant te sit wanneer Hy as koning heers (Mark 10:35-37), verduidelik Jesus aan hulle dat elkeen wat groot wil wees 'n dienaar moet wees (Mark 10:43-44). Wanneer Jesus vir die eerste keer sy lyding aankondig en Petrus Hom eenkant toe neem en berispe (Mark 8:31-32), verduidelik Jesus aan sy dissipels dat dit belangrik is om gehoorsaam te wees aan dit wat God wil. Jesus verduidelik dan dat wat God van 'n mens vra, is om jouself te verloën, jou kruis op te neem en vir Jesus te volg (Mark 8:34).

Dissipelskap en wat dit beteken om vir Jesus te volg, kan uit die drie leringe van Jesus soos volg saamgevat word:

- Eerste lering (Mark 8:34-9:1): Dissipels van Jesus moet bereid wees om in hulleself te sterf en ander belangriker as hulleself te ag. Hulle wat bereid is om ter wille van Jesus gespot te word, is werklik sy dissipels.

6.Van lersel (1989:18-30) deel Markus soos volg in met spesifieke fokus op ruimtes Woestyn (Mark 1:1-13), Galilea (Mark 1:14-8:26), Op pad vanaf Galilea na Woestyn (Mark 1:1-13), Galilea (Mark 1:14-8:26), Op pad vanaf Galilea na
Jerusalem (Mark 8:27-10:52), Jerusalem (Mark 11:1-15:45) en die Graf (Mark 15:46-16:8).
- Tweede lering (Mark 9:35-37): Wanneer mense belangrik wil wees, moet hulle hulleself verneder deur diensbaar aan ander te wees. 'n Dissipel van Jesus is nie iemand wat eer en status najaag nie, maar iemand wat nederig is en bereid is om diensbaar te wees.

- Derde lering (Mark 10:38-45): Niemand wat vir Jesus wil volg, mag daarna streef om bo ander verhewe te wees nie. 'n Dissipel van Jesus is iemand wat eerder self dien, as om gedien te word. Dit was ook die gesindheid waarmee Jesus op aarde geleef het.

Dissipelskap en die betekenis van al drie bogenoemde leringe kan na my mening saamgevat word in Jesus se oproep tot selfverloëning, jou kruis opneem en Hom volg. Daarom word daar nou in die besonder aan elkeen van die dele van Jesus se oproep tot dissipelskap aandag gegee. Bonhoeffer se verstaan van dissipelskap sal ook teen die agtergrond van hierdie oproep, soos verwoord in Markus 8:34, later gelees word.

\section{Jesus se oproep tot dissipelskap in Markus 8:34}

\section{Selfverloëning}

Selfverloëning het in die konteks van die eerste-eeuse Mediterreense wêreld beteken om dit wat in die oë van die wêreld belangrik is, soos mag, gesag, status, eer, jou familie en jy self, minder belangrik te ag as dit wat Jesus van jou vra. Mense wat vir Jesus wil volg, moet nie net hulleself verloën nie, maar ook hulle familie versaak. In hierdie konteks sou dit beteken om byvoorbeeld die familie, wat beskou is as die belangrikste sosiale instelling van die tyd en waarvan 'n mens deel moes wees om jou eer en ook dié van die familie te beskerm, te versaak en vir Jesus te volg. So word iemand wat hierdie besluit neem, opgeneem in 'n nuwe portuurgroep (fictive kin-group), naamlik die huisgesin van God. Malina (2001:132) sluit met die volgende stelling hierby aan: 'But the refashioned synoptic story line, the outcome of such self-denial, then, would be a new ingroup and affiliation to a new kin-group.' Jesus verwys in Markus 10:29-30 na hierdie nuwe portuurgroep waarvan mense wat Hom volg, deel word. ${ }^{7}$

Wat dus in die oë van die wêreld belangrik is, is nie belangrik in die koninkryk van God nie. Dit moet mense leer wat besluit om vir Jesus te volg, en daarom moet hulle hulleself verloën.

\section{Kruis opneem}

Met die familie as voorbeeld word dit duidelik dat selfverloëning en jou kruis opneem met mekaar verweef is. In hierdie verband maak Malina (2001) die volgende opmerking:

Since renouncing one's kin-group is parallel to taking up the cross, it would seem from this saying ${ }^{8}$ that such renunciation is

7.Jesus antwoord: "Dit verseker Ek julle: Daar is niemand wat ter wille van My en ter wille van die evangelie afgesien het van sy huis of broers of susters of moeder ter wille van die evangelie afgesien het van sy huis of broers of susters of moeder of vader of kinders of eiendom nie, ${ }^{30}$ of hy kry nou in hierdie tyd honderd kee soveel: huise en broers en susters en moeders en kinders en eiendom, saam met
baie vervolging, en in die bedeling wat kom, die ewige lewe.'

8.'Wie nie [sy pa] en ma haat soos Ek nie, kan nie my [dissipel] wees nie, en wie [nie] lief is vir [sy pa en] ma soos Ek nie, kan nie my [dissipel] wees nie. Want my ma ... maar my regte [ma] het vir my die lewe gegee' (EvTom 101: eie vertaling uit Engels) 
almost much like self-denial. Further, kin-denial and self-denial would both be equivalent to taking up the cross to follow Jesus. (bl. 115-116)

Net soos selfverloëning word kruis opneem ook verstaan in terme van die versaking van die familie, omdat Jesus mense roep om tot 'n nuwe groep (kin-group) te behoort. Vanuit die sosiale konteks van die tyd beskou, lei 'n positiewe antwoord op Jesus se oproep tot skande. Wanneer mense hulle familie versaak, word hulle eer asook dié van die familie daardeur aangetas omdat hierdie mense skande oor hulle en hulle familie bring. Eer moes ten alle koste beskerm word deur skande te vermy.

Gelykheid en inklusiwiteit is wesenlik deel van die nuwe portuurgroep van mense wat besluit om Jesus te volg en sy dissipels te wees (kyk na Myers 1988:267). Hierdie twee gedagtes is iets wat in die eerste-eeuse Mediterreense wêreld ondenkbaar was omdat ongelykheid en eksklusiwiteit juis hulpmiddels was waardeur eer bekom of herstel is.

Vir Markus was dit nodig dat mense hulle kruis sal dra omdat die saak waaroor dit vir Jesus gegaan het, belangrik was en Hy daardeur ook as die gekruisigde en opgestane Heer bely word.

\section{Navolging van Jesus}

Onderskeid kan getref word tussen twee groepe wat vir Jesus gevolg het. Die eerste was groot groepe wat Jesus gevolg het slegs wanneer Hy in hulle omgewing was. Die ander was ' $n$ kleiner groep, Jesus se twaalf dissipels, wat Hom die heeltyd gevolg het na elke plek waar Hy heen gegaan het. Volgens Stock (1975:203-206) lê die belangrikste verskil tussen die groot groep (skares wat plek- en tydgebonde was in hulle fisiese navolging van Jesus) en die klein groep (Jesus se twaalf dissipels) in die verhouding wat daar tussen Jesus en die groep bestaan het. Jesus het sy twaalf dissipels geroep om by Hom te wees. Stock begrond die dienswerk van die dissipels in hierdie 'by Jesus wees'. Dit is 'n baie belangrike opmerking omdat navolging, hoe vreemd dit ook al mag klink, nie los van Jesus geskied nie.

Hierby sluit Matera (1987:54) aan wanneer hy sê dat om te verstaan wie Jesus werklik is en om Hom te volg, mekaar in die kruis ontmoet. Hy verwoord dit soos volg:

Just as one cannot understand who Jesus is apart from the cross, so one cannot grasp the full meaning of discipleship unless he or she is willing to follow Jesus 'on the way'. (Matera 1987:54)

In Markus bestaan daar dus 'n verband tussen Christologie en dissipelskap. Jesus kan nie los van die kruis gevolg word nie. Dissipelskap beteken om bereid te wees om Jesus te volg en tot aan die einde by Hom te bly. Dissipels moet bereid wees om Jesus se lot ook hulle lot te laat word. Dit gebeur juis omdat dissipels bereid is om in hulleself te sterf omdat hulle ander belangriker as hulleself ag.

Wat Jesus met navolging vra, is ' $\mathrm{n}$ lewe wat bestaan uit diensbaarheid en gehoorsaamheid aan God, tot aan die einde.

\section{Christologie en dissipelskap}

Bonhoeffer het nooit 'n volledig uitgewerkte Christologie daargestel nie. Sy werk hieroor was fragmentaries. Dit laat sy Christologie oop vir 'n verskeidenheid van interpretasies. Na my mening bied die Christologie-lesings wat hy vanaf Mei tot Julie in 1933 aan die Universiteit van Berlyn aangebied het 'n goeie geleentheid om sy Christologie te interpreteer. In hierdie lesings slaan iets deur van sy gedagte dat dissipelskap prakties geleef moet word en dat Christologie en dissipelskap aan mekaar verbind is. Plant (2004) verwys soos volg hierna:

In his lectures in christology, Bonhoeffer realized both the centrality of Christ in theology and of the person of Christ within the christian life...Reading the christology lectures at this point in any case helps to show how Bonhoeffer's discovery of Jesus Christ in 1933 was prerequisite to his theology of discipleship and the common life. (bl. 94)

Bonhoeffer het 'n unieke benadering gevolg in die lesings wat hy aangebied het. Hy het probeer om sy studente die Bybel te laat lees soos dissipels van Jesus, nie soos teologiese studente nie. Hy wou dus hê dat sy studente dit wat hulle in die teks lees ook prakties in gehoorsaamheid aan Christus moes uitleef. As dit nie die geval was nie, sou die lees van die teks geen betekenis hê nie. Metaxas (2010:128) verwys soos volg hierna: 'Bonhoeffer's interest was not only in teaching them as a university lecturer. He wished to "disciple" them in the true life of the Christian.' Hy verduidelik Bonhoeffer se benadering verder: 'Bonhoeffer was not interested in intellectual abstraction. Theology must lead to the practical aspects of how to live as a Christian' (Metaxas 2010:128).

In Bonhoeffer se besware teen religie slaan daar ook iets deur van sy gedagte dat die mens in gehoorsaamheid aan Jesus die eksistensiële besluit neem om Hom te volg. Koekemoer (1988:332-333) verwys na ses besware van Bonhoeffer teen religie, soos geformuleer deur Van Ruler. ${ }^{9}$ Jesus roep mense nie op tot religie nie, maar tot 'n manier van lewe. Hierdie manier van lewe is die navolging van Christus.

'n Belangrike gedagte uit Bonhoeffer se Christologie is dat Jesus nie met fanfare die wêreld ingekom het nie, maar dat Hy incognito diewêreld ingekom hetas'nbedelaaronderbedelaars, as uitgeworpene onder uitgeworpenes, as sterwende onder sterwendes (Bonhoeffer 1966:110). In navolging van Christus moet gelowiges dus ook incognito in hierdie wêreld leef. Dit beteken na my mening 'n gehoorsame leef aan Jesus se oproep tot selfverloëning en die kruis opneem. Gelowiges moet Jesus incognito, as selfverloëndes, end-uit volg.

Koekemoer (1988:335) voer aan dat die indruk geskep word dat Bonhoeffer se Christologie in 'n antropologie verander

9.(i) Religie het te make met die mens se innerlike en word vergeestelik. Dit maak nie erns met die wêreld waarin ' $n$ mens leef nie. (ii) Religie buit die swakheid van die mens uit. (iii) Religie lei daartoe dat die mens sy eie verlosser word. (iv) Daar word op'n ondeurdagte wyse oor die vroomheid van ander gepraat. (v) Religie maak van die Christendom'n verlossingsreligie, wat dit volgens Bonhoeffer nie is nie. Die mens bly volgens Bonhoeffer se gedagte geroepe tot' $n$ taak en verantwoordelikheid in die geskiedenis en nie tot religie nie. Hy lê klem op die feit dat Jesus mense nie oproep tot' $n$ religie nie, maar tot 'n lewe en geloof. Dit is dus'n eksistensiële beslissing wat' $n$ mens moet maak. (vi) Religie is die teendeel van openbaring en geloof' (Koekemoer 1988:332-333). 
omdat dit vir hom eerder om medemenslikheid gaan en omdat geloof vir hom niks anders is as navolging van Jesus nie.

Alhoewel hierdie kritiek teen Bonhoeffer uitgespreek word, is die gedagte van dissipelskap baie prominent in sy Christologie. Daarom kan die stelling met oortuiging gemaak word dat dissipelskap en Christologie vir Bonhoeffer in so 'n mate met mekaar verbind is, dat die een nie sonder die ander kan bestaan nie.

\section{Bonhoeffer se verstaan en uitleef van dissipelskap teen die agtergrond van Jesus se oproep tot navolging in Markus 8:34}

Vervolgens word verwys na Bonhoeffer se verstaan van dissipelskap gelees teen die agtergrond van Jesus se oproep tot dissipelskap in Markus 8:34.

Gehoorsaamheid aan Christus is vir Bonhoeffer onlosmaaklik deel van dissipelskap. Bonhoeffer ([1937] 1995:59) dink soos volg daaroor: 'Discipleship means adherence to Christ, and, because Christ is the object of that adherence, it must take the form of discipleship.' Christus is die objek van gehoorsaamheid. Werklike dissipelskap beteken om nie toe te laat dat daar iets tussen Jesus en die mens se gehoorsaamheid aan Hom kom staan nie.

Bonhoeffer skryf in sy werk oor die etiek, soos aangehaal in Metaxas (2010:363), dat in 'n wêreld waar sukses die maatstaf van alles geword het, die gekruisigde Jesus ' $n$ vreemdeling is wat bejammer word. Sukses, aansien, eer en mag is nie dinge waarin God geïnteresseerd is nie. Hy vra gehoorsaamheid aan Hom, wat ook beteken gehoorsaamheid aan Jesus Christus.

Volgens Bonhoeffer sal húlle staande bly wat, gehoorsaam aan God, met hulle lewe op sy oproep tot dissipelskap antwoord. Sulke mense staan teenoor dié wat hulle rede, beginsels, gewete en vryheid as die standaard vir hulle lewens stel.

Vir Bonhoeffer is dissipelskap nie net ' $n$ abstrakte idee nie. Dit is iets wat prakties in gehoorsaamheid aan Christus geleef moet word. Hy stel dat 'n abstrakte Christologie en geloofskennis alleen dissipelskap uitsluit. Iemand wat Christus navolg, volg nie 'n abstrakte idee na nie, maar vir Christus. Bonhoeffer ([1937] 1995) verwoord dit soos volg:

Christianity without the living Christ is inevitably Christianity without discipleship, and Christianity without discipleship is always Christianity without Christ ... In such a religion, there is trust in God, but no following of Christ. (bl. 59)

Navolging van ons eie idees, of soos wat Bonhoeffer dit noem, dissipelskap sonder Christus, mag lyk na die regte manier van lewe, maar dit is sonder enige belofte. Navolging van
Christus hou die belofte in van dieselfde eindbestemming as dié van Christus wanneer Hy end-uit gevolg word.

In hierdie stelling van Bonhoeffer weerklink Jesus se oproep tot selfverloëning. Die essensie van dissipelskap is die navolging van Christus en nie van 'n mens se eie idees nie. Verloën jouself, want wat Christus van jou vra, is die belangrikste. Bonhoeffer was oortuig daarvan dat Jesus nie nagevolg word bloot as 'n leermeester of iemand wat moraliteit geleer het nie. Vir hom was Jesus die Seun van God en daarom moet Hy gehoorsaam word want dit is eintlik God wat deur Hom aan die woord kom:

Because Jesus is the Christ, He has the authority to call and demand obedience to his word. Jesus summons men to follow Him not as a teacher or a pattern of the good life, but as the Christ, the Son of God. (Bonhoeffer [1937] 1995:58)

Haynes (2003:110) sluit hierby aan: 'Yet for him [Bonhoeffer] Christ was "that determinative center of power and value that is the sovereign reality ..." not a "relative representation or mode of that response" to reality.'

Die impak van gehoorsaamheid aan Jesus se oproep tot dissipelskap som Bonhoeffer ([1937] 1995:89) soos volg op: 'When Christ calls a man, He bids him come and die.' Hoe hy dissipelskap en sy eie roeping verstaan, verduidelik hy in Januarie 1936 in 'n brief aan Elizabeth Zinn:

My calling is quite clear to me. What God will make of it I don't know ... I believe its nobility will become plain to us only in coming times and events. If only we can hold out. (Metaxas 2010:123)

Dit het nooit vir Bonhoeffer gegaan oor 'n oorwinning of 'n stryd wat hy self wen nie. Gehoorsaamheid en ondergeskiktheid aan wat God vra, was vir Hom die belangrikste. Agter hierdie siening van Bonhoeffer slaan selfverloëning en kruis opneem soos wat Jesus dit vra, sterk deur.

Op 21 Januarie 1934 lewer Bonhoeffer 'n preek uit Jeremia. Hierdie preek reflekteer hoe Bonhoeffer sy eie toekoms gesien het as 'n volgeling van Jesus wat homself verloën en sy kruis opgeneem het. Hy het homself gesien as 'n gevangene van God wat net soos die profete van ouds moes ly en onderdruk word. In die aanvaarding hiervan lê vir Bonhoeffer 'n oorwinning. Dit is ' $n$ oorwinning saam met Christus omdat iemand wat Hom wil volg en bereid is om die pad end-uit te stap, nie net geroep word om saam met Christus op die pad te loop nie, maar ook om saam met Hom te sterf (Bonhoeffer [1937] 1995:89).

Elk van die drie dele van Jesus se oproep tot navolging in Markus 8:34 hou verband met Bonhoeffer se lewe as 'n lewe in navolging van Jesus. Vir Bonhoeffer het dit nie vir een oomblik oor homself gegaan nie. Dit blyk onder andere duidelik uit die feit dat hy na Duitsland toe teruggekeer het om leiding te gee aan die kerk asook uit sy siening oor die Joodse vraagstuk. Selfverloëning en jou kruis opneem was 
dus deel van Bonhoeffer se oortuiging dat hy as 'n dissipel van Jesus gehoorsaam aan Hom moes leef.

Hy het Jesus gevolg op die manier wat hy verstaan het Jesus van 'n mens vra wanneer Hy jou roep om Hom te volg. Bonhoeffer se siening was dat wanneer Jesus jou roep om Hom te volg, dit beteken dat jy ook bereid moet wees om vir Hom te sterf. Dat Bonhoeffer hierdie oortuiging geleef het, is duidelik deurdat sy dood die uiteinde daarvan was dat hy Jesus gevolg het en ander hoër as homself geag het.

\section{Gevolgtrekking}

Die doel van hierdie artikel was tweeledig. Eerstens het dit ten doel gehad om Bonhoeffer se verstaan van dissipelskap in konteks te plaas teen die agtergrond van die omstandighede waarin hy in Duitsland in die aanloop tot en tydens die Tweede Wêreldoorlog geleef en gewerk het. Tweedens is daar gekyk of iets van Jesus se oproep tot dissipelskap in Markus neerslag in Bonhoeffer se verstaan daarvan vind.

Met hierdie tweeledige doel in gedagte, kan die volgende gevolgtrekking gemaak word. Die omstandighede waarin Bonhoeffer hom voor en tydens die Tweede Wêreldoorlog bevind het, was uitdagend vir sy oortuiging om gehoorsaam aan en in navolging van Jesus te leef. Dit blyk uit gereelde konfrontasie met die voorstanders van en protes teen die ideologie van die Nasionaal-Sosialisme. Hierdie konfrontasie en protes moet egter nie gesien word as 'n doel op sigself wat Bonhoeffer voor oë gehad het nie. Dit was die gevolg van sy verstaan van dissipelskap as 'n lewe in gehoorsaamheid aan God. ${ }^{10}$ In sy manier van lewe en ook in sy laaste oomblikke het hy sy uitspraak bevestig dat wanneer Jesus jou roep om Hom te volg, Hy jou roep om saam met Hom te sterf. Dit is die keuse wat gemaak moet word en wat Bonhoeffer prakties tot heel aan die einde van sy lewe geleef het.

Selfverloëning en kruis opneem, kom baie duidelik na vore in sy uitleef van dissipelskap. Die hoogtepunt hiervan is na my mening sy besluit om tydens die oorlog nie buite Duitsland te wees nie. Om terug te gaan Duitsland toe kort voor die oorlog, terwyl hy geweet het dat dit rampspoedige gevolge kan hê, getuig daarvan dat hy ander mense en hulle belange bo sy eie gestel het. Dissipelskap was vir Bonhoeffer dus 'n eksistensiële besluit. Daarop volg 'n manier van lewe wat getuig van navolging van Christus.

10.Jesus se optrede en die omkeer van waardes was na my mening nie 'n vorm van protes nie. Sy optrede was gegrond in gehoorsaamheid aan God. Die kernboodskap van sy prediking en lering was dat ' $\mathrm{n}$ ander stel waardes in die koninkryk van God geld as wat in die koninkryk van die wêreld geld. Gesien vanuit die oogpunt van die Romeinse owerheid kon Jesus se optrede wel ' $n$ vorm van protes wees. Die kerugmatiese betekenis van Jesus se optrede lê na my mening eerder in sy gehoorsaamheid aan God as in 'n vorm van protes.
Bonhoeffer se lewe was tot aan die einde 'n vergestalting van selfverloëning, kruis opneem en navolging van Jesus. Dit word duidelik in die woorde van $\mathrm{H}$. Fischer-Hüllstrung, die kampdokter by Flossenburg tydens Bonhoeffer se teregstelling. ${ }^{11}$ Jare na die oorlog beskryf hy Bonhoeffer se laaste oomblikke soos volg:

Through the half open door in one of the huts I saw pastor Bonhoeffer, before taking off his prison garb, kneeling on the floor praying fervently to his God. I was most deeply moved by the way this lovable man prayed, so devout and so certain that God heard his prayer. At the place of execution, he again said a short prayer and then climbed the steps to the gallows, brave and composed. His death ensued after a few seconds. In the almost fifty years I worked as a doctor, I have hardly ever seen a man die so entirely submissive to the will of God. (Metaxas 2010:532)

Dietrich Bonhoeffer het gelewe in die voetspore van Christus.

\section{Erkenning Mededingende belange}

Die outeur verklaar hiermee dat hy geen finansiële of persoonlike verbintenis het met enige party wat hom nadelig of voordelig kon beïnvloed het in die skryf van hierdie artikel nie.

\section{Literatuurverwysings}

Bonhoeffer, D., [1937] 1995, The cost of discipleship, Touchstone, New York, NY. Bonhoeffer, D., 1966, Christology, Collins, London.

Godsey, J.D., 1982, 'More Bonhoeffer-Barth correspondence', IBS Newsletter 22, 2.

Haynes, S.R., 2003, The Bonhoeffer phenomenon: Portraits of a protestant saint, Fortress Press, Minneapolis, MN.

Koekemoer, J.H., 1988, 'Die vraag na "verstaan" in die Christologie van D Bonhoeffer', HTS Teologiese Studies/Theological Studies 44(2), 329-336. http://dx.doi. org/10.4102/hts.v44i2.2209

Malina, B.J., 2001, The social gospel of Jesus: The kingdom of God in Mediterranean perspective, Fortress Press, Minneapolis, MN.

Matera, F.J., 1987, What are they saying about Mark?, Paulist Press, Mahwah, NJ.

Metaxas, E., 2010, Bonhoeffer: Pastor, martyr, prophet, spy: A righteous gentile vs the Third Reich, Thomas Nelson, Nashville, TN.

Moses, J.A., 2002, 'Bonhoeffer's Germany: The political context', in J.W. de Gruchy (ed.), The Cambridge companion to Dietrich Bonhoeffer, pp. 3-21, Cambridge University Press, Cambridge.

Myers, C., 1988, Binding the strong man: A political reading of Mark's story of Jesus, Orbis, New York, NY.

Nelson, F.B., 2002, 'The life of Dietrich Bonhoeffer', in J.W. de Gruchy (ed.), The Cambridge companion to Dietrich Bonhoeffer, pp. 22-49, Cambridge University Press, Cambridge.

Plant, S., 2004, Bonhoeffer, Continuum, New York, NY. (Outstanding Christian thinkers series).

Stock, K., 1975, Boten aus dem Mit-Ihm-Sein: Das Verhaltnis zwischen Jesus und den Zwolf nach Marcus, Biblical Institute Press, Rome. (Analecta Biblica 70).

Van lersel, B.M.F., 1989, Reading Mark, The Liturgical Press, Collegeville, PA.

11.Bonhoeffer is op 06 April 1943 gearresteer. Die rede daarvoor was sy betrokkenheid by die smokkel van Jode uit Duitsland uit (kyk na Nelson 2002:40) asook sy betrokkenheid by'n plan om Hitler te vermoor. 